University of Nebraska - Lincoln

DigitalCommons@University of Nebraska - Lincoln

USDA National Wildlife Research Center - Staff Publications
U.S. Department of Agriculture: Animal and Plant Health Inspection Service

$10-2-1997$

\title{
CYTOCHROME P450 AND ORGANOCHLORINE CONTAMINANTS IN BLACK-CROWNED NIGHT-HERONS FROM THE CHESAPEAKE BAY REGION, USA
}

\author{
Barnett A. Rattner \\ U.S. Geological Survey, brattner@usgs.gov \\ Mark J. Melancon \\ Patuxent Wildlife Research Center, U.S. Department of the Interior \\ Clifford P. Rice \\ Patuxent Wildlife Research Center, U.S. Department of the Interior \\ Walter Riley Jr. \\ Patuxent Wildlife Research Center, U.S. Department of the Interior \\ John D. Eisemann \\ Patuxent Wildlife Research Center, U.S. Department of the Interior, John.D.Eisemann@aphis.usda.gov \\ See next page for additional authors \\ Follow this and additional works at: https://digitalcommons.unl.edu/icwdm_usdanwrc \\ Part of the Environmental Sciences Commons
}

Rattner, Barnett A.; Melancon, Mark J.; Rice, Clifford P.; Riley, Walter Jr.; Eisemann, John D.; and Hines, Randy K., "CYTOCHROME P450 AND ORGANOCHLORINE CONTAMINANTS IN BLACK-CROWNED NIGHTHERONS FROM THE CHESAPEAKE BAY REGION, USA" (1997). USDA National Wildlife Research Center Staff Publications. 566.

https://digitalcommons.unl.edu/icwdm_usdanwrc/566

This Article is brought to you for free and open access by the U.S. Department of Agriculture: Animal and Plant Health Inspection Service at DigitalCommons@University of Nebraska - Lincoln. It has been accepted for inclusion in USDA National Wildlife Research Center - Staff Publications by an authorized administrator of DigitalCommons@University of Nebraska - Lincoln. 


\section{Authors}

Barnett A. Rattner, Mark J. Melancon, Clifford P. Rice, Walter Riley Jr., John D. Eisemann, and Randy K. Hines 


\title{
CYTOCHROME P450 AND ORGANOCHLORINE CONTAMINANTS IN BLACK-CROWNED NIGHT-HERONS FROM THE CHESAPEAKE BAY REGION, USA
}

\author{
Barnett A. Rattner,* Mark J. Melancon, Clifford P. Rice, Walter Riley, Jr., \\ JOHN EISEMANN and RANDY K. Hines \\ Patuxent Wildlife Research Center, U.S. Department of the Interior, 12011 Beech Forest Road, Laurel, Maryland 20708-4041
}

(Received 20 December 1996; Accepted 10 April 1997)

\begin{abstract}
Black-crowned night-heron (Nycticorax nycticorax) offspring were collected from a relatively uncontaminated coastal reference site (next to Chincoteague National Wildlife Refuge, VA, USA) and two sites in the Chesapeake Bay watershed (Baltimore Harbor, MD and Rock Creek Park, Washington, DC, USA). Hepatic microsomal activities of benzyloxyresorufin- $O$-dealkylase and ethoxyresorufin- $O$-dealkylase were significantly elevated (up to sixfold and ninefold induction, respectively) in pipping embryos from the Baltimore Harbor colony compared to the reference site, whereas values in embryos from the Rock Creek Park colony were intermediate. Concentrations of organochlorine pesticides and metabolites in pipping embryos from both sites in the Chesapeake watershed were greater than at the reference site but below the known threshold for reproductive impairment. However, concentrations of 10 arylhydrocarbon receptor-active polychlorinated biphenyl (PCB) congeners and estimated toxic equivalents were up to 37-fold greater in embryos collected from these two sites in the Chesapeake Bay region, with values for toxic congeners 77 and 126 exceeding those observed in pipping heron embryos from the Great Lakes. Monooxygenase activity of pipping embryos was associated with concentrations of several organochlorine pesticides, total PCBs, arylhydrocarbon receptor-active PCB congeners, and toxic equivalents $(r=0.30-0.59)$, providing further evidence of the value of cytochrome P450 as a biomarker of organic contaminant exposure. Organochlorine contaminant levels were greater in 10-d-old nestlings from Baltimore Harbor than the reference site but had no apparent effect on monooxygenase activity or growth. These findings demonstrate induction of cytochrome P450 in pipping black-crowned night-heron embryos in the Chesapeake Bay region, probably by exposure to PCB congeners of local origin, and the accumulation of organochlorine pesticides and metabolites in nestling herons from Baltimore Harbor. Biomonitoring with additional waterbird species (e.g., bald eagle, common tern, great blue heron) that appear to be more sensitive to PCBs than black-crowned night-herons is recommended to document health of waterbirds and remediation of the Chesapeake Bay.
\end{abstract}

Keywords-Biomonitoring Biomarkers Polychlorinated biphenyl congeners Toxic equivalents

\section{INTRODUCTION}

Aside from their ecological role in estuaries, aesthetic value, and consumptive use as a hunted natural resources, many species of waterbirds have served as monitors of environmental health [1,2]. Agricultural, industrial, and urban point and nonpoint source pollution and loss of submerged aquatic vegetation have been recognized as critical factors causing the deterioration of habitats that support waterbirds in the Chesapeake Bay ecosystem [3]. Although the banning of the most harmful organochlorine pesticides and the use of steel shot in place of toxic lead shot have reduced mortality and reproductive problems in birds, other pollutants may still pose a threat to raptors and waterfowl in the Chesapeake [4]. However, the paucity of contaminant exposure data for wading birds in the Chesapeake watershed does not permit an assessment of possible adverse effects on these species [4].

The colonial nesting black-crowned night-heron (Nycticorax nycticorax; $\mathrm{BCNH}$ ) has been used as a biomonitor of potentially contaminated wetlands and estuaries owing to its high trophic level, tendency to bioaccumulate pollutants, widespread distribution, nest site fidelity, and synchrony of nesting. Numerous field studies in Atlantic and Pacific coast estuaries and in the Great Lakes have documented contaminant exposure and associated toxicological effects in this species through measurement of pollutant burdens, biochemical responses, genetic damage, altered reproductive success, and impaired growth rates of young [5-14]. Hepatic cytochrome P450-as-

\footnotetext{
* To whom correspondence may be addressed.
}

sociated monooxygenase activity (P450) is a well-characterized biomarker of organic pollutant exposure in many vertebrates [15-17]. The qualitative and quantitative responsiveness of hepatic $\mathrm{P} 450$ in $\mathrm{BCNHs}$ has been well characterized in laboratory studies, following controlled administration of inducing agents, and in field studies, following uncontrolled exposure to anthropogenic contaminants [18-20].

This communication reports findings of a biomonitoring study describing P450 responses and concentrations of organochlorine pesticides and metabolites and polychlorinated biphenyls (PCBs), including arylhydrocarbon $(A h)$ receptoractive congeners, in BCNHs collected from two colonies in the Chesapeake watershed and a coastal colony in Virginia.

\section{MATERIALS AND METHODS}

\section{Collection sites}

In May of 1991, BCNH offspring were collected from three colonies. A colony in Chincoteague Bay next to the Chincoteague National Wildlife Refuge (CNWR; 37 $56^{\prime} \mathrm{N}, 75^{\circ} 25^{\prime} \mathrm{W}$ ), Northhampton County, Virginia, USA, served as a relatively uncontaminated coastal reference site. Based on previous contaminant monitoring studies in BCNHs [6,18-20], eggs and young collected from Chincoteague Bay have been documented to have low concentrations of organochlorine pesticides and PCBs.

The Baltimore Harbor colony $\left(\mathrm{BH} ; 39^{\circ} 14^{\prime} \mathrm{N}, 76^{\circ} 13^{\prime} \mathrm{W}\right)$ is located in a small woodlot at the Baltimore Gas and Electric Company's Synthetic Natural Gas Plant in Maryland and was 
presumed to be polluted by urban and industrial contaminants. Herons from this colony concentrate their foraging activity in some of the most highly industrialized areas within the Chesapeake estuary $[21,22]$. In $\mathrm{BH}$, sediment concentrations of $\mathrm{Cr}$, $\mathrm{Pb}, \mathrm{Zn}$, chlordane, and PCBs exceed the adverse effects threshold for aquatic organisms [23], high levels of $\mathrm{Cd}$ and other metals have been observed in shellfish, health advisories on consumption of several finfish species are in effect due to chlordane contamination, and there is historic evidence of harmful effects (eggshell thinning, impaired reproduction, death) in birds and other wildlife [24].

Black-crowned night-herons in the Rock Creek Park colony ( RCP; $38^{\circ} 55^{\prime} \mathrm{N}, 77^{\circ} 02^{\prime} \mathrm{W}$ ) nest in trees above the aviary at the Smithsonian Institution National Zoological Park in Washington, DC, USA. Originally viewed as a potential reference site, it was subsequently learned that birds from this colony not only forage at the Zoological Park at Rock Creek but have also been observed to feed in the Potomac and Anacostia rivers (Paul E. Tomassoni, personal communication), which is well within their foraging range [22]. Toxicological investigations of the upper Potomac and Anacostia rivers have revealed elevated concentrations of $\mathrm{Cd}, \mathrm{Pb}, \mathrm{Zn}, \mathrm{PCBs}$, chlordane, and DDT in sediment, impaired survival of invertebrates and striped bass prolarvae in bioassay studies, and high incidence of histopathological lesions in fish tissue [24]. Furthermore, chlordane and PCB contamination have resulted in health advisories on consumption of several finfish species [24]. Contaminants are presumed to have adversely affected many species of birds in these rivers in the 1960s and 1970s. In the lower Potomac, a 1972 to 1973 collection of barn owls (Tyto alba) revealed elevated $p, p^{\prime}$-DDE concentrations in $15 \%$ of the population that would have been detrimental to reproduction [25]. However, concentrations of total PCBs and organochlorine pesticides in eggs of green herons (Butorides striatus) collected from the lower Potomac in 1972 to 1973 were below concentrations believed to affect reproduction in this species [6]. However, prey selection by green herons (fish, insects, aquatic and terrestrial invertebrates, lower vertebrates) is at a somewhat lower level of the food chain compared to BCNHs (fish, insects, eggs and young birds, small mammals, amphibians) [26].

\section{Sample collections}

Each BCNH colony was visited at least twice a week for about 1 month. Nests were marked with flagging and reproduction was monitored for purposes of sample collection. A single pipping embryo was collected randomly from each of 20 nests at CNWR and at BH. A single nestling $(10 \pm 1 \mathrm{~d}$ of age) was collected from 10 of the 20 earlier chosen nests at each of these colonies. Due to disturbance and logistical difficulties at the RCP colony located within the grounds of the National Zoological Park, a single pipping embryo was collected from only five nests. These eggs were transported in a portable incubator to the Patuxent Wildlife Research Center where they were artificially incubated $\left(37.6^{\circ} \mathrm{C}\right.$ at $68-70 \%$ relative humidity) for about 1 to $2 \mathrm{~d}$ at which time pipping was determined by the protrusion of the egg tooth from the shell. Nestlings were not collected at the RCP colony.

Within $1 \mathrm{~h}$ of collection (CNWR and $\mathrm{BH}$ colonies) or at pipping (artificially incubated RCP samples), each embryo and nestling was macroscopically examined, weighed, and then decapitated. The liver was removed (gall bladder discarded), minced in a cryotube containing glycerol $(2: 1 \mathrm{w} / \mathrm{v})$, and then snap-frozen in liquid nitrogen. The remains of each $\mathrm{BCNH}$ embryo or nestling were placed in chemically clean jars (ICHEM Research, New Castle, DE USA) for subsequent contaminant analyses. These samples were transported on dry ice and stored frozen (liver samples: $-70^{\circ} \mathrm{C}$; nestling and egg samples: $\left.-10^{\circ} \mathrm{C}\right)$.

\section{Determination of cytochrome P450-associated monooxygenase activities}

The activities of 3 dealkylases (benzyloxyresorufin- $O$-dealkylase, BROD; ethoxyresorufin- $O$-dealkylase, EROD; and pentoxyresorufin- $O$-dealkylase, PROD) were determined from the rate of formation of fluorescent product as previously described [18] and more recently adapted to a computer-coupled microwell plate scanner [27]. Briefly, liver samples were thawed and homogenized, and hepatic microsomes were prepared by differential centrifugation. Twenty-four random field samples in triplicate, a reference sample in quadruplicate, and a 10-point standard curve in duplicate were included in each 96-well microtiter plate. Buffer (66 mM Tris-HCl, $\mathrm{pH} 7.4$ ) and substrate $(2.5 \mu \mathrm{M}$ for EROD and $5 \mu \mathrm{M}$ for BROD and PROD) were manually pipetted into the wells of the microtiter plate. Following a 10 -min preassay incubation at $37^{\circ} \mathrm{C}$, the reaction was initiated by the addition of $250 \mu \mathrm{M}$ NADPH in buffer. Eight readings were taken at 90-s intervals using a fluorescent plate scanner (Fluoroscan II; ICN Flow Laboratories, McLean, VA, USA). Assay conditions were optimized so that each well gave a linear response over time that was proportional to the amount of microsomes and fell within the range of the standard curve. Substrate concentrations gave a maximum velocity that was relatively constant over the duration of the assay. Microsomal protein concentration was determined by the method of Lowry et al. [28]. Activity of these dealkylases was expressed as picomoles of product formed per minute per milligram of microsomal protein. All pipping embryo samples were assayed in a 2-d period, and several weeks later all nestling samples were assayed in a 2-d period.

Organochlorine pesticide, total PCBs, and PCB congener analyses

Pipping embryos (including yolk sac; excluding liver) and nestling carcasses (liver and digestive tract removed) were individually homogenized, mixed with anhydrous sodium sulfate (quantity 25 times the sample weight), and Soxhlet-extracted with hexane. The extract was carefully concentrated to dryness and weighed for lipid determination. The lipid extract was then dissolved in petroleum ether and processed through florisil cleanup to remove fatty interferences for subsequent gas chromatographic analysis. Silica gel chromatography was used to separate organochlorine pesticides from PCBs [29]. Individual PCB congeners were isolated and analyzed by the method of Hong and Bush [30], where the silica-gel-isolated PCB fraction was further processed by passing it through an AX-21 carbon/silica gel column. This procedure separates the non-ortho and mono-ortho coplanar PCB congeners from the nonplanar PCB congeners. The pesticides and PCBs in each of the final fractions were quantified with a gas-liquid chromatograph equipped with a ${ }^{63} \mathrm{Ni}$ electron capture detector. Residues in $10 \%$ of the samples were confirmed by gas chromatography/mass spectrometry. The lower limit of detection was $10 \mathrm{ng} / \mathrm{g}$ for organochlorine pesticides and metabolites and $50 \mathrm{ng} / \mathrm{g}$ for total PCBs. The lower limit of detection for individual PCB congeners was $10 \mathrm{pg} / \mathrm{g}$. 
Table 1. Morphological observations and organochlorine contaminant wet weight concentrations in pipping black-crowned night-herons collected from Virginia, Maryland, and Washington, DC, USA ${ }^{\mathrm{a}}$

\begin{tabular}{|c|c|c|c|}
\hline & $\begin{array}{c}\text { Chincoteague } \\
\text { National Wildlife } \\
\text { Refuge, VA }\end{array}$ & $\begin{array}{c}\text { Baltimore Harbor, } \\
\text { MD }\end{array}$ & $\begin{array}{l}\text { Rock Creek Park, } \\
\text { Washington, DC }\end{array}$ \\
\hline$N$ & 20 & 20 & 5 \\
\hline Body weight (g) & $28.6 \pm 0.8$ & $29.6 \pm 0.6$ & $29.7 \pm 0.8$ \\
\hline Body weight less yolk sac (g) & $23.6 \pm 0.6$ & $24.3 \pm 0.8$ & $26.7 \pm 1.4$ \\
\hline Liver weight (mg) & $439 \pm 32$ & $486 \pm 26$ & $506 \pm 60$ \\
\hline Liver : body weight ratio $\times 100(\mathrm{~g} / 100 \mathrm{~g})$ & $1.85 \pm 0.09$ & $1.98 \pm 0.10$ & $1.90 \pm 0.23$ \\
\hline$p, p^{\prime}-\mathrm{DDD}(\mu \mathrm{g} / \mathrm{g})$ & $(\mathrm{ND}-0.03)$ & $\begin{array}{c}0.07 \\
(\mathrm{ND}-0.48)\end{array}$ & $\begin{array}{c}0.03 \\
(\mathrm{ND}-0.24)\end{array}$ \\
\hline$p, p^{\prime}-\mathrm{DDE}(\mu \mathrm{g} / \mathrm{g})$ & $\begin{array}{c}0.23 \mathrm{~B} \\
(\mathrm{ND}-11.8)\end{array}$ & $\begin{array}{c}1.59 \mathrm{~A} \\
(0.35-22.0)\end{array}$ & $\begin{array}{c}1.39 \mathrm{~A} \\
(0.85-3.9)\end{array}$ \\
\hline$p, p^{\prime}-\mathrm{DDT}(\mu \mathrm{g} / \mathrm{g})$ & $(\mathrm{ND}-0.03)$ & $\begin{array}{c}0.02 \\
(\mathrm{ND}-2.7)\end{array}$ & $(\mathrm{ND}-0.01)$ \\
\hline Dieldrin $(\mu \mathrm{g} / \mathrm{g})$ & $\begin{array}{c}0.02 B \\
(\mathrm{ND}-0.16)\end{array}$ & $\begin{array}{c}0.27 \mathrm{~A} \\
(0.06-1.25)\end{array}$ & $\begin{array}{c}0.18 \mathrm{~A} \\
(0.10-0.38)\end{array}$ \\
\hline Heptachlor epoxide $(\mu \mathrm{g} / \mathrm{g})$ & $(\mathrm{ND}-0.04)$ & $\begin{array}{c}0.03 \\
(\mathrm{ND}-0.10)\end{array}$ & $\begin{array}{c}0.05 \\
(0.02-0.14)\end{array}$ \\
\hline$\alpha$-Chlordane $(\mu \mathrm{g} / \mathrm{g})$ & $(\mathrm{ND}-0.02)$ & $\begin{array}{c}0.02 \\
(\mathrm{ND}-0.06)\end{array}$ & $\begin{array}{c}0.02 \\
(\mathrm{ND}-0.06)\end{array}$ \\
\hline Cis-nonachlor $(\mu \mathrm{g} / \mathrm{g})$ & $\begin{array}{c}0.01 \mathrm{~B} \\
(\mathrm{ND}-0.04)\end{array}$ & $\begin{array}{c}0.06 \mathrm{~A} \\
(\mathrm{ND}-0.25)\end{array}$ & $\begin{array}{c}0.06 \mathrm{~A} \\
(0.01-0.11)\end{array}$ \\
\hline Oxychlordane $(\mu \mathrm{g} / \mathrm{g})$ & $(\mathrm{ND}-0.05)$ & $\begin{array}{c}0.07 \\
(0.03-0.25)\end{array}$ & $(\mathrm{ND}-0.15)$ \\
\hline Total PCBs $(\mu \mathrm{g} / \mathrm{g})$ & $\begin{array}{c}0.29 \mathrm{~B} \\
(\mathrm{ND}-1.21)\end{array}$ & $\begin{array}{c}3.40 \mathrm{~A} \\
(1.20-18.8)\end{array}$ & $\begin{array}{c}2.64 \mathrm{~A} \\
(0.70-4.60)\end{array}$ \\
\hline
\end{tabular}

${ }^{a}$ Morphological measurements are expressed as mean \pm SE. Contaminant concentrations are geometric means and extremes (in parentheses); ND $=$ not detected; $-=$ no mean calculated as contaminant was detected in fewer than half of the samples. Site values in a row followed by the same capital letter are not significantly different by Tukey's HSD method of multiple comparison $(P<0.05)$.

\section{Toxic equivalents of $P C B$ congeners}

The potential toxicity of $A h$ receptor-active PCB congeners in each sample was estimated by summing the products of their measured concentrations and toxic equivalency factors (TEFs). Two sets of TEFs were used, including those derived from a broad range of toxic responses in mammals [31] and $50 \%$ lethal dose (LD50) estimates in avian eggs [32]. The potential toxicity of the congeners present in each embryo is expressed as toxic equivalents (TEQs) in $\mathrm{pg} / \mathrm{g}$ of sample.

\section{Statistical analyses}

Body and liver weights, P450-associated monooxygenase activities, contaminant concentrations, contaminant body burdens, and TEQs were tested for homogeneity of variance using the $F$-max test. Monooxygenase activities, contaminant concentrations (when detected in more than one-half of the samples), body burdens, and TEQs were $\log _{10}$-transformed to stabilize variances for statistical analyses. A value one-half the lower limit of detection was assigned to samples with undetectable contaminant concentrations. Differences among collection sites were compared by one-way analysis of variance (ANOVA), and Tukey's HSD method of multiple comparison [33] was used as a mean separation procedure. In addition, monooxygenase responses and contaminant concentrations and body burdens were compared between pipping embryo and nestling siblings by factorial ANOVA [age (pipping embryo, nestling) $\times$ study location $(\mathrm{CNWR}, \mathrm{BH})]$, using nest as a blocking factor. Monooxygenase activities, contaminant concentrations, and TEQs were examined for linear relationships using Pearson product-moment correlation.

\section{RESULTS}

\section{Pipping BCNH embryos}

Morphological observations. No gross abnormalities were observed in any of the 45 pipping embryos. Neither body weight, liver weight, nor the ratio of liver to body weight differed among sites (Table 1).

Cytochrome P450-associated monooxygenase responses. Log-transformed hepatic microsomal activities of BROD and EROD differed $(p<0.05)$ among collection sites. Activity of these monooxygenases was greater $(p<0.05)$ in pipping embryos from $\mathrm{BH}$ compared to CNWR, and activity of embryos collected from RCP was intermediate relative to the other sites (Fig. 1). Inspection of individual values revealed that many $\mathrm{BH}$ and RCP embryos had monooxygenase activity that exceeded the CNWR reference site mean by more than two standard deviations (number of embryos exceeding CNWR reference site mean +2 SDs: $\mathrm{BH}=10$ of 20 for BROD and 5 of 20 EROD; RCP $=3$ of 5 BROD and 2 of 5 EROD). Activity of PROD did not differ among study sites (extreme values: 11.6-69.1 pmol/min/mg).

Contaminant concentrations. Of 15 organochlorine pesticides or their metabolites quantified, concentrations of $p, p^{\prime}-$ DDE were greatest and significantly elevated $(p<0.05)$ in embryos from BH and RCP compared to CNWR (Table 1). One embryo from CNWR and two embryos from BH had $p, p^{\prime}-$ DDE concentrations exceeding $8 \mu \mathrm{g} / \mathrm{g}$ wet weight. In addition, dieldrin and $c i s$-nonachlor values were also greater $(p<0.05)$ in embryos from the $\mathrm{BH}$ and RCP sites. Concentrations of other organochlorine pesticides (Table 1) were low (generally $<0.1 \mu \mathrm{g} / \mathrm{g}$ wet weight) or rarely detected (endrin, $\gamma$-hexachlorocyclohexane, hexachlorobenezene, mirex, $o, p$-DDE, 

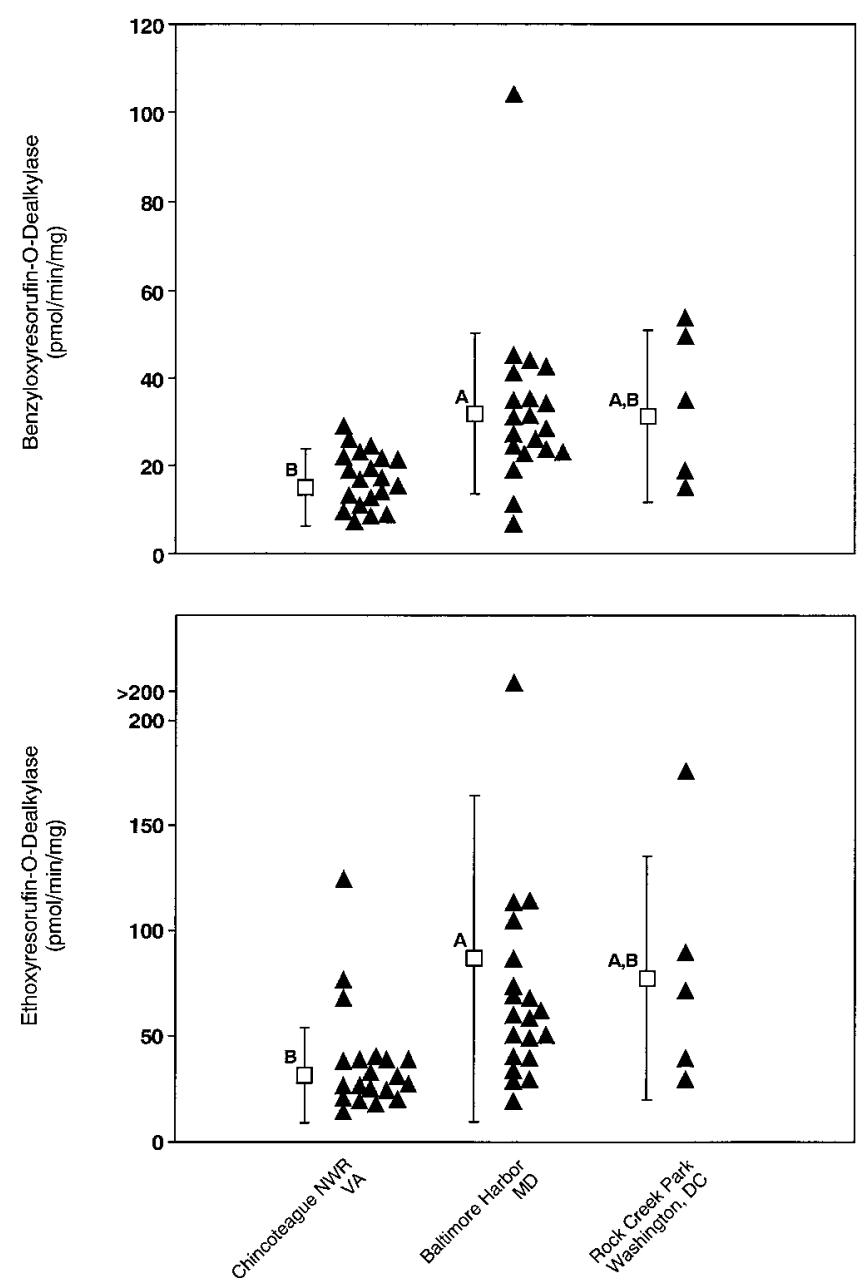

Fig. 1. Hepatic microsomal BROD and EROD activities (mean \pm SD and individual observations) of pipping BCNHs collected near Chincoteague National Wildlife Refuge, Virginia (reference site), Baltimore Harbor, Maryland, and Rock Creek Park, Washington, DC, USA. The high EROD value from Baltimore Harbor is $350 \mathrm{pmol} / \mathrm{min} / \mathrm{mg}$. Sites that share capital letters are not significantly different by Tukey's HSD method of comparison $(p<0.05)$.

$o, p$-DDT, and $\gamma$-chlordane) in embryos from the three study sites. Concentrations of total PCBs in embryos from $\mathrm{BH}$ and $\mathrm{RCP}$ averaged an order of magnitude greater $(p<0.05)$ than at CNWR.

Thirteen $A h$ receptor-active PCB congeners were quantified in a chosen subset of 36 embryos (Table 2). With the exception of low values for congener 169, the geometric mean of 12 of these congeners in $\mathrm{BH}$ embryos was 3-37-fold greater $(p<$ $0.05)$ than that of CNWR embryos. A similar trend in congener concentrations was observed in RCP embryos. As expected from these trends, predicted TEQs of BH and RCP embryos were 20-fold and 9-fold greater $(p<0.05)$ than noted in CNWR embryos.

Relation among morphological observations, cytochrome P450, and contaminant concentrations. Weight of pipping embryos (without yolk sac) was neither associated with logtransformed hepatic activities of BROD and EROD nor concentrations of detectable contaminants (organochlorine pesticides and their metabolites, total PCBs, and PCB congeners) and TEQs $(p>0.05)$. As previously noted [18], activities of log-transformed BROD and EROD were interrelated $(p<$ $0.05 ; r=0.86 ; N=45$ embryos), but unlike previous obser- vations [18], PROD activity was also related to these monooxygenases ( $p<0.05 ; r=0.60$ and 0.69$)$. Log-transformed BROD and EROD activities were associated with the concentration of several organochlorine pesticides and metabolites (dieldrin, heptachlor epoxide, $\alpha$-chlordane, $\gamma$-chlordane, and cis-nonachlor; $p<0.05 ; r=0.37-0.54 ; N=45)$, total PCBs $(p<0.05 ; r=0.50$ and $0.55 ; N=45), 10 A h$ receptor-active PCB congeners (numbers 77, 126, 66, 81, 105, 114, 118, 156, 157 , and $189 ; p<0.05 ; r=0.30-0.59 ; N=36)$, and TEQs $(p<0.05 ; r=0.48-0.53 ; N=36)$.

\section{Ten-day-old nestling BCNH}

Morphological observations. Body weight, carcass weight, liver weight, and the ratio of liver to body weight did not differ between the CNWR and BH study sites (Table 3 ).

Cytochrome P450-associated monooxygenase responses. Log-transformed hepatic microsomal activities of BROD, EROD, and PROD did not differ among collection sites. Upon inspection of individual values, only one $\mathrm{BH}$ nestling had elevated monooxygenase activity (i.e., BROD) that exceeded the CNWR reference site mean by more than two standard deviations.

Contaminant concentrations. Concentrations of organochlorine pesticides or their metabolites in nestling carcasses were generally lower than observed in pipping embryos (Table 3 vs Table 1). Concentrations of 9 of the 15 compounds quantified were greater $(p<0.05)$ in nestlings from BH compared to CNWR (Table 3). Other organochlorine pesticides and metabolites (dieldrin, endrin, hexachlorobenezene, mirex, $o, p$ DDE, $o, p$-DDT, $p, p^{\prime}$-DDT) were detected in fewer than half of the samples. Average concentrations of total PCBs in nestlings from $\mathrm{BH}$ were over eightfold greater $(p<0.05)$ than at CNWR.

Relation among morphological observations, cytochrome $P 450$, and contaminant concentrations. Body weight of nestlings was not associated with log-transformed hepatic monooxygenase activities ( $p>0.05 ; N=20$ ). However, body weight (but not carcass weight) was inversely related to logtransformed concentrations of $p, p^{\prime}$-DDD, $p, p^{\prime}$-DDE, $\alpha$-chlordane, $\gamma$-chlordane, and total PCBs $(p<0.05 ; r=-0.48$ to -0.50). Although log-transformed BROD, EROD, and PROD activities in nestlings were interrelated $(p<0.05 ; r=0.68-$ 0.86 ), monooxygenase activities were not associated with logtransformed contaminant concentrations.

\section{Cytochrome P450 and contaminant concentrations and} body burdens in sibling embryos and nestlings

A subset of the pipping embryos and nestlings were siblings ( $N=10$ nests from CNWR and 10 nests from BH). Factorial ANOVA of this subset confirmed most of the aforementioned geographic differences, namely that sibling pipping embryos and nestlings from $\mathrm{BH}$ are exposed to more contaminants than those from CNWR (Fig. 1 and Tables 1 and 3). Furthermore, factorial ANOVA also indicated that pipping embryos have greater contaminant concentrations than nestlings (Fig. 1 and Table 1 vs Table 3).

To further evaluate posthatching contaminant exposure at CNWR and $\mathrm{BH}$, the body burden (i.e., total mass of a contaminant) of several contaminants was compared between sibling pipping embryos and nestlings. For eight frequently detected organochlorines, body burden was estimated by determining the product of contaminant concentration $(\mu \mathrm{g} / \mathrm{g}$ wet weight) and carcass weight ( $\mathrm{g}$ wet weight). Inspection of sib- 
Table 2. Arylhydrocarbon receptor-active PCB congener wet weight concentrations and predicted toxic equivalents in pipping black-crowned night-herons collected from Virginia, Maryland, and Washington, DC, USA $^{\mathrm{a}}$

\begin{tabular}{|c|c|c|c|}
\hline & $\begin{array}{l}\text { Chincoteague } \\
\text { National Wild- } \\
\text { life Refuge, VA }\end{array}$ & $\begin{array}{l}\text { Baltimore } \\
\text { Harbor, MD }\end{array}$ & $\begin{array}{c}\text { Rock Creek Park, } \\
\text { Washington, DC }\end{array}$ \\
\hline$N$ & 11 & 20 & 5 \\
\hline $\begin{array}{l}\text { Congener } 77(\mathrm{pg} / \mathrm{g}) \\
\quad\left(3,3^{\prime}, 4,4^{\prime} \text {-tetraCB }\right)\end{array}$ & $\begin{array}{l}508 \mathrm{~B} \\
(110-1,570)\end{array}$ & $\begin{array}{c}\text { 4,982A } \\
(130-22,520)\end{array}$ & $\begin{array}{l}4,988 \mathrm{~A} \\
(1,560-18,700)\end{array}$ \\
\hline $\begin{array}{l}\text { Congener } 126(\mathrm{pg} / \mathrm{g}) \\
\left(3,3^{\prime}, 4,4^{\prime}, 5 \text {-pentaCB }\right)\end{array}$ & $(\mathrm{ND}-750)$ & $\begin{array}{l}4,527 \\
(\mathrm{ND}-39,640)\end{array}$ & $\begin{array}{l}1,611 \\
(310-4,410)\end{array}$ \\
\hline $\begin{array}{l}\text { Congener } 169(\mathrm{pg} / \mathrm{g}) \\
\quad\left(3,3^{\prime}, 4,4^{\prime}, 5,5^{\prime}-\text { hexaCB }\right)\end{array}$ & $\begin{array}{c}32 \\
(\mathrm{ND}-190)\end{array}$ & $(\mathrm{ND}-2,210)$ & $(\mathrm{ND}-1,400)$ \\
\hline $\begin{array}{l}\text { Congener } 66(\mathrm{ng} / \mathrm{g}) \\
\quad\left(2,3^{\prime}, 4,4^{\prime} \text {-tetraCB }\right)\end{array}$ & $\begin{array}{c}2.63 \mathrm{~B} \\
(0.55-7.90)\end{array}$ & $\begin{array}{r}58.22 \mathrm{~A} \\
(5.60-210)\end{array}$ & $\begin{array}{r}36.22 \mathrm{~A} \\
(16.7-144)\end{array}$ \\
\hline $\begin{array}{l}\text { Congener } 81(\mathrm{ng} / \mathrm{g}) \\
\quad\left(3,4,4^{\prime}, 5 \text {-tetraCB }\right)\end{array}$ & $\begin{array}{c}0.04 \mathrm{~B} \\
(0.01-0.50)\end{array}$ & $\begin{array}{c}1.19 \mathrm{~A} \\
(0.01-19.6)\end{array}$ & $\begin{array}{l}\text { 0.60A,B } \\
(0.01-8.70)\end{array}$ \\
\hline $\begin{array}{l}\text { Congener } 105(\mathrm{ng} / \mathrm{g}) \\
\quad\left(2,3,3^{\prime}, 4,4^{\prime} \text {-pentaCB }\right)\end{array}$ & $\begin{array}{c}5.62 \mathrm{~B} \\
(0.30-13.8)\end{array}$ & $\begin{array}{c}145.90 \mathrm{~A} \\
(47.90-1,045)\end{array}$ & $\begin{array}{c}83.15 \mathrm{~A} \\
(29.2-182)\end{array}$ \\
\hline $\begin{array}{l}\text { Congener } 114(\mathrm{ng} / \mathrm{g}) \\
\left(2,3,4,4^{\prime}, 5 \text {-pentaCB }\right)\end{array}$ & $\begin{array}{c}0.52 \mathrm{~B} \\
(0.17-7.80)\end{array}$ & $\begin{array}{r}5.16 \mathrm{~A} \\
(0.18-19.9)\end{array}$ & $\begin{array}{c}5.82 \mathrm{~A} \\
(2.10-13.8)\end{array}$ \\
\hline $\begin{array}{l}\text { Congener } 118(\mathrm{ng} / \mathrm{g}) \\
\quad\left(2,3^{\prime}, 4,4^{\prime}, 5 \text {-pentaCB }\right)\end{array}$ & $\begin{array}{c}10.16 \mathrm{~B} \\
(\mathrm{ND}-76.4)\end{array}$ & $\begin{array}{r}288.39 \mathrm{~A} \\
(62.6-939)\end{array}$ & $\begin{array}{c}214.1 \mathrm{~A} \\
(94.7-493)\end{array}$ \\
\hline $\begin{array}{l}\text { Congener } 123(\mathrm{ng} / \mathrm{g}) \\
\left(2^{\prime}, 3,4,4^{\prime}, 5 \text {-pentaCB }\right)\end{array}$ & $\begin{array}{c}0.41 \\
(0.07-1.30)\end{array}$ & $\begin{array}{c}1.26 \\
(\mathrm{ND}-11.8)\end{array}$ & $\begin{array}{c}4.36 \\
(2.30-11.2)\end{array}$ \\
\hline $\begin{array}{l}\text { Congener } 156(\mathrm{ng} / \mathrm{g}) \\
\left(2,3,3^{\prime}, 4,4^{\prime}, 5-\mathrm{hexaCB}\right)\end{array}$ & $\begin{array}{c}1.19 \mathrm{~B} \\
(0.30-2.30)\end{array}$ & $\begin{array}{c}15.18 \mathrm{~A} \\
(4.30-44.1)\end{array}$ & $\begin{array}{c}9.53 \mathrm{~A} \\
(3.80-18.7)\end{array}$ \\
\hline $\begin{array}{l}\text { Congener } 157(\mathrm{ng} / \mathrm{g}) \\
\quad\left(2,3,3^{\prime}, 4,4^{\prime}, 5^{\prime}-\text { hexaCB }\right)\end{array}$ & $\begin{array}{c}1.66 \mathrm{~B} \\
(\mathrm{ND}-5.50)\end{array}$ & $\begin{array}{r}62.18 \mathrm{~A} \\
(22.70-184)\end{array}$ & $\begin{array}{c}47.54 \mathrm{~A} \\
(16.7-87.2)\end{array}$ \\
\hline $\begin{array}{l}\text { Congener } 167(\mathrm{ng} / \mathrm{g}) \\
\quad\left(2,3^{\prime}, 4,4^{\prime}, 5,5^{\prime}-\text { hexaCB }^{\prime}\right)\end{array}$ & $\begin{array}{c}2.52 \mathrm{~B} \\
(0.30-7.90)\end{array}$ & $\begin{array}{l}26.01 \mathrm{~A} \\
(\mathrm{ND}-106)\end{array}$ & $\begin{array}{l}\text { 3.78A,B } \\
(\mathrm{ND}-75.2)\end{array}$ \\
\hline $\begin{array}{l}\text { Congener } 189(\mathrm{ng} / \mathrm{g}) \\
\left(2,3,3^{\prime}, 4,4^{\prime}, 5,5^{\prime} \text {-heptaCB }\right)\end{array}$ & $\begin{array}{c}0.43 \mathrm{~B} \\
(0.01-1.00)\end{array}$ & $\begin{array}{r}5.59 \mathrm{~A} \\
(0.01-27.8)\end{array}$ & $\begin{array}{c}10.69 \mathrm{~A} \\
(3.60-23.2)\end{array}$ \\
\hline $\begin{array}{l}\text { Predicted toxic equivalents based } \\
\text { on mammalian toxic potencies } \\
\text { (pg/g) } \\
\text { Predicted toxic equivalents based } \\
\text { upon LD50 in avian eggs } \\
\text { (pg/g) }\end{array}$ & $83 \pm 18 \mathrm{~B}$ & $1,691 \pm 206 \mathrm{~A}$ & $775 \pm 210 \mathrm{~A}$ \\
\hline
\end{tabular}

a Values for PCB congeners are geometric means and extremes (in parentheses); ND = not detected; - = no mean calculated as contaminant was detected in fewer than half of the samples. Potency estimates are expressed as arithmetic mean \pm SE. Site values in a row followed by the same capital letter are not significantly different by Tukey's HSD method of multiple comparison $(p<0.05)$.

ling values and statistical analysis of these data (ANOVA: age $\times$ location using nest as a blocking factor when the contaminant was detected in more than half of the samples) revealed that burdens of $p, p^{\prime}$-DDD, heptachlor epoxide, $\alpha$-chlordane, $\gamma$-chlordane, cis-nonachlor, and total PCBs were greater in nestlings than in sibling pipping embryos, and values were higher at $\mathrm{BH}$ than at CNWR (Table 4). However, dieldrin burdens in 8 of 10 pipping embryos from $\mathrm{BH}$ were actually greater than in their sibling nestlings. Burdens of $p, p^{\prime}$-DDE were greater in 6 of $10 \mathrm{BH}$ pipping embryos compared to sibling nestlings.

Monooxygenase activities in sibling pipping embryos and nestlings were not associated ( $p>0.05 ; N=20$ ). However, log-transformed values of 7 of 15 contaminants in pipping embryos and nestlings ( $p, p^{\prime}$-DDD, $p, p^{\prime}$-DDE, $p, p^{\prime}$-DDT, $\alpha$ chlordane, cis-nonachlor, heptachlor epoxide, and total PCBs) were significantly correlated $(p<0.05 ; r=0.48-0.78 ; N=$ 20).

\section{DISCUSSION}

\section{Contaminant exposure of heron embryos and nestlings}

Organochlorine pesticides and metabolites, total PCBs, and $\mathrm{PCB}$ congeners in pipping and nestling BCNHs collected at the CNWR reference site in 1991 were low and generally quite comparable to values reported in a 1989 collection [18-20]. However, concentrations of these contaminants in BCNHs from $\mathrm{BH}$ and RCP (only pipping embryos) were often greater than reference site values, with mean $p, p^{\prime}$-DDE, other organochlorine pesticides, and total PCB concentrations equaling or exceeding levels reported in contemporarily collected BCNHs from many sites in San Francisco Bay and the Columbia River [13,14,18-20]. As expected, levels of $p, p^{\prime}$-DDE and total PCBs were less than those observed in BCNHs collected from presumably more contaminated sites in the Great Lakes and certain north Atlantic coast estuaries over the past several decades $[6,10,12,18-20,34]$. Despite these intermediate levels of total PCBs in $\mathrm{BH}$ and RCP herons, concentrations of several $A h$ receptor-active PCB congeners (notably potent planar congeners 77 and 126) were markedly greater than observed in pipping BCNHs from the Great Lakes [19]. For example, concentrations of potent congeners 77 and 126 in $\mathrm{BH}$ (Table 2) were 10-fold and 4-fold greater than values in pipping BCNHs from Cat Island in Green Bay, Wisconsin, USA [19]. Furthermore, TEQs in these samples approached previously reported values observed in the pipping embryos from the Great Lakes [19]. 
Table 3. Morphological observations, cytochrome P450-associated monooxygenase activities, and organochlorine contaminant wet weight concentrations in nestling black-crowned night-herons from Virginia and Maryland, USA ${ }^{\mathrm{a}}$

\begin{tabular}{|c|c|c|}
\hline & $\begin{array}{l}\text { Chincoteague National } \\
\text { Wildlife Refuge, VA }\end{array}$ & Baltimore Harbor, MD \\
\hline$N$ & 9 & 10 \\
\hline Body weight $(\mathrm{g})$ & $328.5 \pm 13.0$ & $269.9 \pm 11.2$ \\
\hline Carcass weight (g) & $216.4 \pm 8.3$ & $197.8 \pm 9.9$ \\
\hline Liver weight $(\mathrm{g})$ & $16.8 \pm 0.7$ & $15.9 \pm 0.8$ \\
\hline Liver : body weight ratio $\times 100(\mathrm{~g} / 100 \mathrm{~g})$ & $5.1 \pm 0.2$ & $5.3 \pm 0.2$ \\
\hline $\begin{array}{l}\text { Benzyloxyresorufin- } O \text {-dealkylase } \\
\quad(\mathrm{pmol} / \mathrm{min} / \mathrm{mg})\end{array}$ & $28.0 \pm 4.4$ & $33.7 \pm 4.6$ \\
\hline $\begin{array}{l}\text { Ethoxyresorufin- } O \text {-dealkylase } \\
\quad(\mathrm{pmol} / \mathrm{min} / \mathrm{mg})\end{array}$ & $58.3 \pm 9.5$ & $65.6 \pm 8.1$ \\
\hline $\begin{array}{l}\text { Pentoxyresorufin- } O \text {-dealkylase } \\
\quad(\mathrm{pmol} / \mathrm{min} / \mathrm{mg})\end{array}$ & $49.9 \pm 6.1$ & $43.9 \pm 4.8$ \\
\hline$p, p^{\prime}-\mathrm{DDD}(\mu \mathrm{g} / \mathrm{g})$ & $\begin{array}{c}0.01 \\
(\mathrm{ND}-0.02)\end{array}$ & $\begin{array}{c}0.02 * \\
(0.02-0.03)\end{array}$ \\
\hline$p, p^{\prime}-\mathrm{DDE}(\mu \mathrm{g} / \mathrm{g})$ & $\begin{array}{c}0.06 \\
(0.03-0.14)\end{array}$ & $\begin{array}{c}0.13^{*} \\
(0.07-0.45)\end{array}$ \\
\hline Heptachlor epoxide $(\mu \mathrm{g} / \mathrm{g})$ & $\begin{array}{c}0.01 \\
(\mathrm{ND}-0.02)\end{array}$ & $\begin{array}{c}0.03 * \\
(0.02-0.06)\end{array}$ \\
\hline$\gamma$-Hexachlorocyclohexane $(\mu \mathrm{g} / \mathrm{g})$ & $\begin{array}{c}0.02 \\
(\mathrm{ND}-0.06)\end{array}$ & $\begin{array}{c}0.06^{*} \\
(\mathrm{ND}-0.60)\end{array}$ \\
\hline$\alpha$-Chlordane $(\mu \mathrm{g} / \mathrm{g})$ & $\begin{array}{c}0.01 \\
(\mathrm{ND}-0.01)\end{array}$ & $\begin{array}{c}0.03^{*} \\
(0.02-0.09)\end{array}$ \\
\hline$\gamma$-Chlordane $(\mu \mathrm{g} / \mathrm{g})$ & $\begin{array}{c}0.01 \\
(\mathrm{ND}-0.01)\end{array}$ & $\begin{array}{c}0.02 * \\
(0.01-0.03)\end{array}$ \\
\hline Cis-nonachlor $(\mu \mathrm{g} / \mathrm{g})$ & $\begin{array}{c}0.01 \\
(0.01-0.02)\end{array}$ & $\begin{array}{c}0.03 * \\
(0.02-0.05)\end{array}$ \\
\hline Oxychlordane $(\mu \mathrm{g} / \mathrm{g})$ & $\begin{array}{c}0.01 \\
(\mathrm{ND}-0.02)\end{array}$ & $\begin{array}{c}0.02 * \\
(0.01-0.04)\end{array}$ \\
\hline Total PCBs $(\mu \mathrm{g} / \mathrm{g})$ & $\begin{array}{c}0.15 \\
(\mathrm{ND}-0.61)\end{array}$ & $\begin{array}{c}1.29 * \\
(0.56-2.1)\end{array}$ \\
\hline
\end{tabular}

${ }^{a}$ Morphological measurements and monooxygenase activities are expressed as mean \pm SE. Contaminant concentrations are geometric means and extremes (in parentheses); ND = not detected; - no mean calculated as contaminant was detected in fewer than half of the samples. Values followed by asterisk are significantly different $(p<0.05)$ from Chincoteague National Wildlife Refuge site by analysis of variance.

Table 4. Organochlorine contaminant body burdens ( $\mu \mathrm{g} / \mathrm{carcass})$ in pipping embryo and nestling siblings from Virginia and Maryland, USA ${ }^{\mathrm{a}}$

\begin{tabular}{|c|c|c|c|c|}
\hline & \multicolumn{2}{|c|}{$\begin{array}{c}\text { Chincoteague National Wildlife } \\
\text { Refuge, VA }\end{array}$} & \multicolumn{2}{|c|}{ Baltimore Harbor, MD } \\
\hline & Pipping embryo & Nestling & Pipping embryo & Nestling \\
\hline$N$ & 10 & 10 & 10 & 10 \\
\hline$p, p^{\prime}-\mathrm{DDD}$ & $\begin{array}{c}0.22 \\
(\mathrm{ND}-0.98)\end{array}$ & $\begin{array}{c}2.00 \\
(1.04-4.14)\end{array}$ & $\begin{array}{c}2.23 \\
(0.96-8.37)\end{array}$ & $\begin{array}{c}4.60 \\
(2.99-6.62)\end{array}$ \\
\hline$p, p^{\prime}-\mathrm{DDE}$ & $\begin{array}{c}6.33 \\
(2.34-27.0)\end{array}$ & $\begin{array}{c}11.91 \\
(\mathrm{ND}-34.6)\end{array}$ & $\begin{array}{c}26.74 \\
(16.3-186)\end{array}$ & $\begin{array}{c}25.02 \\
(12.4-67.3)\end{array}$ \\
\hline Dieldrin & $\begin{array}{c}0.48 \\
(0.13-1.40)\end{array}$ & $(\mathrm{ND}-4.14)$ & $\begin{array}{c}7.89 \\
(1.99-26.4)\end{array}$ & $(\mathrm{ND}-22.1)$ \\
\hline Heptachlor epoxide & $(\mathrm{ND}-1.44)$ & $\begin{array}{c}2.64 \\
(\mathrm{ND}-4.52)\end{array}$ & $\begin{array}{c}0.71 \\
(0.16-1.93)\end{array}$ & $\begin{array}{c}5.80 \\
(2.99-12.3)\end{array}$ \\
\hline$\alpha$-Chlordane & $(\mathrm{ND}-0.69)$ & $\begin{array}{c}2.00 \\
(\mathrm{ND}-2.49)\end{array}$ & $\begin{array}{c}0.64 \\
(0.14-2.90)\end{array}$ & $\begin{array}{c}5.83 \\
(2.99-13.9)\end{array}$ \\
\hline$\gamma$-Chlordane & $(\overline{\mathrm{ND}})$ & $\begin{array}{c}1.63 \\
(\mathrm{ND}-2.47)\end{array}$ & $(\mathrm{ND}-1.00)$ & $\begin{array}{c}3.54 \\
(1.50-4.97)\end{array}$ \\
\hline Cis-nonachlor & $\begin{array}{c}0.31 \\
(\mathrm{ND}-0.83)\end{array}$ & $\begin{array}{c}2.30 \\
(1.71-4.14)\end{array}$ & $\begin{array}{c}1.89 \\
(0.58-5.44)\end{array}$ & $\begin{array}{c}5.24 \\
(3.00-11.0)\end{array}$ \\
\hline Total PCBs & $\begin{array}{c}9.95 \\
(2.66-33.7)\end{array}$ & $\begin{array}{c}32.83 \\
(12.3-150)\end{array}$ & $\begin{array}{c}83.61 \\
(34.4-277)\end{array}$ & $\begin{array}{c}252.34 \\
(114-472)\end{array}$ \\
\hline
\end{tabular}

${ }^{a}$ Contaminant burdens are geometric means and extremes (in parentheses); ND $=$ not detected; $-=$ no mean calculated as contaminant was detected in fewer than half of the samples. 
It has long been recognized that the geographic source of lipophilic contaminants transferred from the hen to the egg and embryo is unclear; pollutant burdens might be accumulated by hens prior to migration or acquired at the nesting site. Organochlorine contaminants in heron eggs and embryos from the Atlantic coast [5], Great Lakes [18], and San Francisco Bay [13] have been attributed to local exposure, whereas contaminants in BCNH eggs from relatively uncontaminated sites in the southwestern United States are believed to reflect accumulations in wintering grounds in Mexico [35]. Certainly the presence of organochlorine pesticides and PCBs in sediments and invertebrates and fish (BCNH prey items) [23,24] of the Anacostia and Potomac rivers and $\mathrm{BH}$ represent potential exposure sources of hens just prior to or immediately after nesting.

Contaminant exposure at breeding sites is more clearly assessed with nestlings whose local food source (a few kilometers from nest) and rapid growth diminishes the influence of in ovo pollutants. Evidence, and even an estimate, of heron nestling exposure in $\mathrm{BH}$ was obtained by comparing total body burdens of contaminants in pipping embryos to those of nestlings. Upon comparing pipping embryo and nestling BCNHs from both $\mathrm{CNWR}$ and $\mathrm{BH}$, the total mass of six organochlorine contaminants (Table 4) ranged from 2 to 10 times greater in nestlings, thereby documenting exposure. However, dieldrin and $p, p^{\prime}$-DDE burdens were apparently greater in $\mathrm{BH}$ pipping embryos compared to nestlings, which could be due to a low level exposure and enhanced contaminant metabolism in the more developed nestling. A rough estimate of the daily organochlorine contaminant accumulation rate ([burden in embryo minus burden in nestling]/10 $\mathrm{d}$ of age $=$ total $\mu \mathrm{g}$ accumulated/d; excludes effect of age-related increases in food consumption) yielded values of $0.51 \mu \mathrm{g} / \mathrm{d}$ for heptachlor epoxide, $0.52 \mu \mathrm{g} / \mathrm{d}$ for $\alpha$-chlordane, $0.34 \mu \mathrm{g} / \mathrm{d}$ for cis-nonachlor, and $16.8 \mu \mathrm{g} / \mathrm{d}$ for total PCBs. Notably, accumulation rates for these organochlorine pesticides and metabolites in $\mathrm{BCNH}$ young from $\mathrm{BH}$ are remarkably similar to those reported in Green Bay, Wisconsin, USA [12], although the accumulation rate for total PCBs is $61 \%$ lower.

\section{Contaminant effects in heron embryos and nestlings}

Body and organ weights of pipping embryo and nestling BCNHs collected at the CNWR site in 1991 were quite comparable to values observed in 1989 [18,20]. Monooxygenase activities in these offspring were relatively low, further substantiating the use of this colony as a relatively uncontaminated reference site.

In the present study, there was no evidence of teratogenesis, impaired growth, or hepatomegaly (liver enlargement) in pipping BCNHs from the $\mathrm{BH}$ and RCP sites, although such toxic effects have been documented in heron colonies in San Francisco Bay [7,13] and the Great Lakes, USA [10] and were shown to be related to organochlorine pesticide and PCB exposure. Furthermore, both BCNH colonies appear to be reproducing well [21,22] (Paul E. Tomassoni, personal communication), with the concentration of $p, p^{\prime}$-DDE in $90 \%$ of the samples below the $8-\mu \mathrm{g} / \mathrm{g}$ threshold associated with impaired reproduction [36]. Nonetheless, hepatic microsomal activities of BROD and EROD in pipping BCNHs were significantly elevated at the $\mathrm{BH}$ and RCP sites, although the magnitude of induction in most affected individuals was considerably less than that observed in embryos from the Great Lakes [18]. Activities of these monooxygenases in BCNHs were as- sociated with concentrations of some organochlorine pesticide and metabolites, total PCBs, $A h$ receptor-active PCB congeners, and TEQs as previously reported [19]. Aside from serving as a biomarker of organic pollutant exposure, the biological consequences of monooxygenase induction can include enhanced detoxication and elimination of xenobiotics, alterations of endogenous steroid metabolism, and generation of reactive metabolites causing toxic injury $[16,17]$. Such biochemical effects may foreshadow other subtle and adverse consequences of contaminants at higher levels of biological organization.

Despite the interrelation of contaminant concentrations in sibling embryos and nestlings and evidence of accumulation of contaminants of local origin in nestlings, hepatic monooxygenase activity was apparently unaffected in nestlings from the $\mathrm{BH}$ site. This may be attributed to a number of factors in nestlings including relatively larger liver size, more fully developed detoxicative mechanisms, differences in exposure (smaller and less contaminated prey items fed to nestlings vs larger and more contaminated prey items consumed by adults whose burdens are in part transferred into the egg), dilution and distribution of contaminants in rapidly growing young, and even an age-related difference of sensitivity to induction. These observations are in agreement with findings from the Great Lakes and San Francisco Bay, USA [20], suggesting that monooxygenase activity is a less robust biomarker of organic contaminant exposure and effects in rapidly growing nestlings compared to sibling pipping embryos.

\section{Implications for health of BCNHs and the Chesapeake Bay watershed}

Based upon these and other findings in BCNHs, conclusions on their health and that of the watershed are limited, in that merely two locations (both disturbed and highly populated by man) were studied. Flourishing reproduction and apparently normal growth of young suggest that anthropogenic contaminants are well below toxicological effect thresholds for BCNHs at these sites. Furthermore, a recent study assessing genotoxic damage at several $\mathrm{BCNH}$ colonies did not detect alterations in the coefficient of variation of DNA content in blood and spleen cells of BCNH embryos and nestlings at the $\mathrm{BH}$ colony compared to the reference CNWR site [11]. However, induction of cytochrome $\mathrm{P} 450$ in pipping embryos, probably by exposure to toxic $A h$ receptor-active PCB congeners of local origin and the accumulation of organochlorine contaminants by $\mathrm{BH}$ nestlings demonstrate the bioavailability of potentially toxic contaminants and may foreshadow effects at higher levels of biological organization, including the population level. Based upon both laboratory and field observations, several other species of waterbirds (e.g., bald eagle, common tern, great blue heron) appear to be more sensitive to PCBs than BCNHs [32] and could be at risk in the Chesapeake Bay watershed. It is recommended that additional avian species in the watershed be evaluated and monitored in order to document the health of waterbird resources and remediation of the estuary.

Acknowledgement-We thank the Chesapeake Bay Field Office of the Fish and Wildlife Service for providing financial support for portions of this study, Paul E. Tomassoni for assistance in collecting BCNH eggs at Rock Creek Park, William Link and Lois Loges for advice in the statistical analysis of the data, Kinard Boone for graphical presentation of results, and David J. Hoffman for critically reviewing a draft of the manuscript. 


\section{REFERENCES}

1. Furness, R.W. and J.J.D. Greenwood. 1993. Birds as Monitors of Environmental Change. Chapman and Hall, London, UK.

2. Kushlan, J.A. 1993. Colonial waterbirds as bioindicators of environmental change. Colon. Waterbirds 16:223-251.

3. Erwin, R.M., G.M. Haramis, D.G. Krementz and S.L. Funderburk. 1993. Resource protection for waterbirds in Chesapeake Bay. Environ. Manage. 17:613-619.

4. Heinz, G.H. and S.N. Wiemeyer. 1991. Effects of contaminants on birds. In S.L. Funderburk, S.J. Jordan, J.A. Mihursky and D. Riley, eds., Habitat Requirements for Chesapeake Bay Living Resources, 2nd ed. Chesapeake Bay Program, U.S. Environmental Protection Agency, Annapolis, MD, pp. 23-1-23-9

5. Ohlendorf, H.M., E.E. Klaas and T.E. Kaiser. 1978. Environmental pollutants and eggshell thinning in the black-crowned night heron. In A. Sprunt IV, J.C. Ogden and S. Winckler, eds., Wading Birds. Research Report 7. National Audubon Society, New York, NY, USA, pp. 63-82.

6. Ohlendorf, H.M., E.E. Klaas and T.E. Kaiser. 1979. Environmental pollutants and eggshell thickness: Anhingas and wading birds in the eastern United States. U.S. Fish Wildl. Serv. Spec. Sci. Rep. Wildl. 216.

7. Hoffman, D.J., B.A. Rattner, C.M. Bunck, A. Krynitsky, H.M. Ohlendorf and R.W. Lowe. 1986. Association between PCBs and lower embryonic weight in black-crowned night herons in San Francisco Bay. J. Toxicol. Environ. Health 19:383-391.

8. Ohlendorf, H.M., T.W. Custer, R.W. Lowe, M. Rigney and E. Cromartie. 1988. Organochlorines and mercury in eggs of coastal terns and herons in California, USA. Colon. Waterbirds 11: 85-94.

9. Custer, T.W., B.A. Rattner, H.M. Ohlendorf and M.J. Melancon. 1991. Herons and egrets as proposed indicators of estuarine contamination in the United States. Int. Ornithol. Cong. 20:2474-2479.

10. Hoffman, D.J., G.J. Smith and B.A. Rattner. 1993. Biomarkers of contaminant exposure in common terns and black-crowned night-herons in the Great Lakes. Environ. Toxicol. Chem. 12: 1095-1103.

11. Custer, T.W., J.W. Bickham, T.B. Lyne, T. Lewis, L.A. Ruedas, C.M. Custer and M.J. Melancon. 1994. Flow cytometry for monitoring contaminant exposure in black-crowned night-herons. Arch. Environ. Contam. Toxicol. 27:176-179.

12. Custer, T.W. and C.M. Custer. 1995. Transfer and accumulation of organochlorines from black-crowned night-heron eggs to chicks. Environ. Toxicol. Chem. 14:533-536.

13. Hothem, R.L., D.L. Roster, K.A. King., T.J. Keldsen, K.C. Marois and S.E. Wainwright. 1995. Spatial and temporal trends of contaminants in eggs of wading birds from San Francisco Bay, California. Environ. Toxicol. Chem. 14:1319-1331.

14. Blus, L.J., B.A. Rattner, M.J. Melancon and C.H. Henny. 1996. Reproduction of black-crowned night-herons related to predation and contaminants in Oregon and Washington. Colon. Waterbirds (in press).

15. Payne, J.F., L.F. Fancey, A.D. Rahimtula and E.L. Porter. 1987. Review and perspective on the use of mixed-function oxygenase enzymes in biological monitoring. Comp. Biochem. Physiol. C 86:233-245.

16. Rattner, B.A., D.J. Hoffman and C.M. Marn. 1989. Use of mixed-function oxygenases to monitor contaminant exposure in wildlife. Environ. Toxicol. Chem. 8:1093-1102.

17. Stegeman, J.J., M. Brouwer, R.T. DiGiulio, L. Forlin, B.A. Fowler, B.M. Saunders and P.A. Van Veld. 1992. Molecular responses to environmental contamination: Enzyme and protein systems as indicators of chemical exposure and effect. In R.J. Huggett, R.A. Kimerle, P.M. Merle, Jr. and H.L. Bergman, eds., Biomarkers: Biochemical, Physiological and Histological Mark- ers of Anthropogenic Stress. Lewis, Boca Raton, FL, USA, pp. 237-339.

18. Rattner, B.A., et al. 1993. Biomonitoring environmental contamination with pipping black-crowned night-heron embryos: Induction of cytochrome P450. Environ. Toxicol. Chem. 12:17191732.

19. Rattner, B.A., J.S. Hatfield, M.J. Melancon, T.W. Custer and D.E. Tillitt. 1994. Relation among cytochrome P450, Ah-active PCB congeners and dioxin equivalents in pipping black-crowned night-heron embryos. Environ. Toxicol. Chem. 13:1805-1812.

20. Rattner, B.A., M.J. Melancon, T.W. Custer and R.L. Hothem. 1996. Cytochrome P450 and contaminant concentrations in nestling black-crowned night-herons and their interrelation with sibling embryos. Environ. Toxicol. Chem. 15:715-721.

21. Erwin, R.M., V.P. Anders and K. Miles-Iverson. 1990. Industrial strength herons. Outdoors in Maryland Spring: 14

22. Erwin, R.M., J.S. Hatfield and W.A. Link. 1991. Social foraging and feeding environment of the black-crowned night-heron in an industrialized estuary. Bird Behav. 9:94-102.

23. National Oceanic and Atmospheric Administration. 1994. Assessment of chemical contaminants in the Chesapeake and Delaware bays. NOAA/NOS, Silver Spring, MD, USA.

24. U.S. Environmental Protection Agency. 1994. Chesapeake Bay basinwide toxics reduction strategy reevaluation report. CBP/TRS 117/94. Annapolis, MD.

25. Klass, E.E., S.N. Wiemeyer, H.M. Ohlendorf and D.M. Swineford. 1978. Organochlorine residues, eggshell thickness, and nest success in barn owls from the Chesapeake Bay. Estuaries 1:4653.

26. Erlich, P.R., D.S. Dobkin and D. Wheye. 1988. The Birder's Handbook: A Field Guide to the Natural History of North American Birds. Simon and Schuster, New York, NY, USA.

27. Melancon, M.J. 1996. Development of cytochromes P450 in avian species as a biomarker for environmental contaminant exposure and effect: Procedures and baseline values. In D.A. Bengtson and D.S. Henshel, eds., Environmental Toxicology and Risk Assessment: Biomarkers and Risk Assessment, Vol. 5. STP 1306. Philadelphia, PA, USA, pp. 95-108.

28. Lowry, O.H., N.J. Rosebrough, A.L. Farr and R.J. Randall. 1951. Protein measurements with the Folin phenol reagent. $J$. Biol. Chem. 193:265-275.

29. Cromartie, E.W., et al. 1975. Residues of organochlorine pesticides and polychlorinated biphenyls and autopsy data for bald eagles, 1971-72. Pestic. Monit. J. 9:11-14.

30. Hong, C. and B. Bush. 1990. Determination of mono- and nonortho coplanar PCBs in fish. Chemosphere 2:173-181.

31. Safe, S. 1990. Polychlorinated biphenyls (PCBs), dibenzo-p-dioxins (PCDDs), dibenzofurans (PCDFs), and related compounds: Environmental and mechanistic considerations which support the development of toxic equivalency factors (TEFs). Crit. Rev. Toxicol. 21:51-88.

32. Hoffman, D.J., C.P. Rice and T.J. Kubiak. 1996. PCBs and dioxins in birds. In W.N. Beyer, G.H. Heinz and A.W. RedmonNorwood, eds., Environmental Contaminants in Wildlife: Interpreting Tissue Concentrations. CRC/Lewis, Boca Raton, FL, USA, pp. 165-207.

33. Kirk, R.E. 1968. Experimental Design: Procedures for the Behavioral Sciences. Brooks/Cole, Belmont, CA, USA.

34. Custer, T.W., C.M. Bunck and T.E. Kiaser. 1983. Organochlorine residues in Atlantic coast black-crowned night-herons, 1979. Colon. Waterbirds 6:160-167.

35. Henny, C.J. and L.J. Blus. 1986. Radiotelemetry locates wintering grounds of DDE-contaminated black-crowned night-herons. Wildl. Soc. Bull. 14:236-241.

36. Henny, C.J., L.J. Blus, A.J. Krynitsky and C.M. Bunck. 1984. Current impact of DDE on black-crowned night-herons in the intermountain west. J. Wildl. Manage. 48:1-13. 